\title{
The Formation, Development and Contribution of the New Ideals in Education
}

\section{Conferences, $1914-1937$.}

\section{Introduction}

In a seminal and much-cited article in the journal Paedagogica Historica, the historian Kevin Brehony provided a detailed exploration of the origins of the New Education Fellowship (hereafter referred to as the NEF) as well as its influence and importance in disseminating many of its key ideas across a range of international - mostly European - settings. ${ }^{1}$ Of course, the argument presented there was more than mere narrative and the discussion was enlivened and made more complex by his wider consideration of the contribution of the NEF to the development of practitioner knowledge and (more widely) the social sciences including identifying the various strategies adopted by particular conference delegates in order to further such progressive ambitions. By so doing, Brehony's work was thus contributing to an area which had long proven ripe for scholarly investigation and other recent pieces have likewise explored the significance of that movement. ${ }^{2}$ However, whilst this glut of publications has been welcome, what is equally noteworthy is the contrasting lack of scholarly interest paid to a series of gatherings which could in many ways be considered as the forerunner of the NEF - notably the New Ideals in Education conferences. This is perhaps all the more surprising given, as we shall see, the close relationship that existed not just

\footnotetext{
${ }^{1}$ See Kevin J. Brehony, 'A New Education for a New Era: the Contribution of the Conferences of the New Education Fellowship to the Disciplinary Field of Education 1921-1938' in Paedagogica Historica 40, no. 5-6 (2004), 733-755.

${ }^{2}$ Aside from Brehony, see for example Margaret White, 'The New Education Fellowship: An International Community of Practice' in New Era in Education 82, no. 3 (2001) 71-75, C.M Jenkins, 'The Professional Middle Class and the Social Origins of Progressivism: a Case Study of the New Education Fellowship, (PhD diss, Institute of Education, University of London) 1989 and Celia Jenkins, 'New Education and its Emancipatory Interests' in History of Education 29, no.2 (2000) 139-175.
} 
between the News Ideals grouping and the NEF but also the New Ideals conferences and the emergent Theosophical Fraternity in Education, founded in $1915 .^{3}$

Alluded to only briefly within Brehony, this tangential acknowledgement is typical of writing within the history of education discipline more generally; a search of the literature reveals for example few publications focussing explicitly upon these connections. Aside from a short piece by M.D. Lawson, the only other works concentrating exclusively on the personal and professional relations between these various groups are unpublished conference papers and theses. ${ }^{4}$ Within wider historical scholarship, mention of the New Ideals conferences has usually only been as a way of noting a particular individual's attendance or else as seeing the meetings as indicative of a more general movement towards co-operation following the First World War. ${ }^{5}$ Even a work as definitive as that of R.J.W. Selleck - although conceding the 'enthusiasm and vitality' ${ }^{6}$ of the meetings - still only devotes one paragraph to their endeavours, preferring typically to focus on the activities of the apparently more radical and prestigious NEF.

Part of the reason for this scholarly neglect may stem from the diffuse nature of the conference records themselves. There is only one extant copy (in the British Library) of the complete published pamphlets of those early conferences held between 1914 and 1923 whilst

\footnotetext{
${ }^{3}$ The Theosophical Fraternity in Education was founded in 1915 by leading Theosophists including Beatrice Ensor who had become disillusioned with the horrors of the First World War. The Fraternity was also to grow out of a more general desire to import Theosophist ideas into British schools and Theosophical Education Trusts had existed since 1913. According to Lawson (1981) by 1919 the Fraternity had 560 members. ${ }^{4}$ See M.D. Lawson, 'The New Education Fellowship: the Formative Years' in Journal of Educational Administration and History 13, no, 2 (1981) 24-28, Kevin J. Brehony, "A Dedicated Spiritual Movement': Theosophists and Education 1875-1939', Paper presented at ISCHE XIX, National University of Ireland, Maynooth, 1997; Kevin J. Brehony, 'To Letchworth via India: The Transformation of the Theosophical Educational Trust', Paper presented at ISCHE XXXIV, University of Geneva and Sue Middleton, 'NEF's "Prequel": New Zealand Theosophists in 'New Education' Networks, 1890s-1938', Paper presented at the annual conference of ANZHES (Australian and New Zealand History of Education Society), Victoria, University of Wellington, 2015.

${ }^{5}$ Indicative of this trend would be a work such as Allen Warren, 'Sir Robert Baden-Powell, the Scout Movement and Citizen Training in Great Britain, 1900-1920' in English Historical Review 101, no. 399 (1986), 376-398. ${ }^{6}$ R.J.W. Selleck, English Primary Education and the Progressives, 1914-1939 (London, Boston, Routledge \& Kegan Paul, 1972), 45.
} 
the proceedings of the last three gatherings from 1935 - 1937 exist only within the archive of the London IUCL Institute of Education, London. The interim years of 1924 and 1934 saw meetings continuing to be held (with the exception of 1924); however, their records were not published in the previous format - essentially compendiums of papers. Instead, notice of these meetings formed part of the newly founded New Ideals Quarterly, which was the official journal for the New Ideals Committee and which was set up to 'link together those who attended its conferences and to give continuity to the movement. ${ }^{7}$ Again, a full set of these is to be found only within a handful of copyright institutions. To compound the diffuse and partialness of the record, even those accounts that do exist seem not to include any mention of subsidiary events taking place such as fringe talks, network activities or additional discussion panels, goings-on which seem certain given the comparatively lengthy duration of each of the conferences. ${ }^{8}$ Furthermore, those speakers whose papers are listed are not always well known today, being as they were mostly interested and enthusiastic contemporary practitioners and academics.

There is also something of a contrast to be drawn between the nature of the New Ideals conferences and their more widely acknowledged contemporary counterparts. Whilst it is true that, limited transport and communication technologies notwithstanding, texts written by key members of the group enjoyed a wide readership and international circulation, the New Ideals meetings themselves were reflective of a more parochial character. In particular, their participants were, for the most part, drawn from the British Isles and their presentations were often influenced by specific local classroom initiatives or domestic changes in the Board of Education's policy. Even the choices of venue - three early conferences were held in Stratford-upon-Avon and four in Oxford - could have hardly been more quintessentially

\footnotetext{
7'Editorial' in New Ideals Quarterly, vol. 1 no. 1, 3.

${ }^{8}$ The 1914 conference lasted four days, the 1915 conference six whilst the rest were to be for the duration of a week.
} 
English in character, a fact remarked upon in a written preface to the records of 1916, which spoke of the "informal association of friends... [working] under pleasant conditions." ${ }^{9}$ There is much, then, to suggest that these conferences had about them the loose and informal feel of a gathering of like-minded discursive and enthusiastic practitioners rather than a formal society meeting, a point perhaps emphasised by the absence of delegates and papers in both 1919 and 1923 due to their dates coinciding with those of school terms!

That is not to say of course that these events have gone completely unheralded; the centenary of the 1914 Montessori conference at East Runton (out of which grew the New Ideals conferences) was for example acknowledged at ISCHE $36 .{ }^{10}$ Moreover, in an unpublished online paper heavily constructed through the utterances of the participants themselves, Michael Newman (a house parent at Summerhill and long-term advocate of the ideas of A.S. Neill) has drawn attention to their importance in seeking to give a clear - and very early articulation in relation to the rights of children, at a stroke therefore transforming their character from that of an informal teacher gathering to instead being at the forefront of reshaping our understanding of the role and position of the child through engagement with wider discourses. However, as we have mentioned, beyond that there is very little existent published scholarship on these events or this movement despite the fact that, in total, the conferences covered a span of 23 years (from 1914-1937) and, in addition to the many practicing teachers, attendees to the meetings also included the 'big beasts' of early twentieth century progressivism such as Edmond Holmes, Edward O’ Neill, Homer Lane, Margaret McMillan and Percy Nunn. There were also occasional papers offered by such luminaries as Robert Baden-Powell and the future Poet Laureate John Masefield who, by virtue of their

\footnotetext{
9'Introductory' in New Ideals in Education: $3^{\text {rd }}$ Conference Papers (London: New Ideals Committee, 1916), vi.

${ }^{10}$ ISCHE (International Standing Conference for the History of Education) is an international organization dedicated to furthering cooperation within the discipline across nations. Founded in 1978, ISCHE 36 , as the name would suggest, was the $36^{\text {th }}$ of their annual conferences and was held in London between 23-26 July 2014. Its theme was Education, War and Peace.
} 
attendance and interest, were offering tacit support and recognition of these new and outwardly exciting ideas. Whilst many of these individuals have themselves been the basis of fine pieces of (often biographical) scholarship, ${ }^{11}$ no-where then has the significance of their collective attendance at these conferences really been made apparent.

This omission is particularly striking given the centrality to the history of education of networks, personal connections and the sharing of good practice - a point stressed by Peter Cunningham in his discussion of prosopography, which placed great importance upon the notion of collective biography and the way in which the influence of even those lesser known educational figures can be seen as contributing to the development of ideology within educational thought and practice. ${ }^{12}$ Equally important - and perhaps less abstract - has been the recent work of those such as Eckhardt Fuchs who has also sought to address issues relating to the exchange of ideas in the history of education. He has been particularly keen to emphasise the way in which 'Networked processes and organizations...determine political power', ${ }^{13}$ and this is apposite in relation to the New Ideals movement given, as we shall see, its close connection and relationship to contemporary figures of authority and the reciprocal exchange of ideas which played a part in determining policy. Furthermore, many of the protagonists involved in the New Ideals meetings were themselves embedded in complex relational webs with those of both the NEF and the Theosophist Fraternity. For example, both

\footnotetext{
${ }^{11}$ Examples of such biographical scholarship include Catherine Burke “"The School Without Tears": E.F. O'Neill of Prestolee' in History of Education 34, no. 3 (2005) 263-275 on Edward O'Neill, Judith Stinton A Dorset Utopia: the Little Commonwealth and Homer Lane, (Norwich: Black Dog Books, 2005) on Homer Lane and Carolyn Steedman, Childhood, Culture and Class in Britain: Margaret McMillan, 1860-1931 (London: Virago, 1990) and Elizabeth Bradburn, Margaret McMillan: Portrait of a Pioneer (London, New York, Routledge, 1989) on Margaret McMillan.

${ }^{12}$ See Peter Cunningham, 'Innovators, Networks and Structures: Towards a Prosopography of Progressivism' in History of Education 30, no.5 (2001): 433-451.

${ }^{13}$ Eckhardt Fuchs, 'Networks and the History of Education' in Paedagogica Historica, 43, no. 2 (2007), 185. See as well Eckhardt Fuchs, 'The Creation of New International Networks in Education: The League of Nations and Educational Organizations in the 1920s' in Paedagogica Historica, 43, no. 2 (2007), 199-209.
} 
Margaret McMillan and Maria Montessori joined the Theosophical Society ${ }^{14}$ whilst Lord Lytton - co-founder of the New Ideals conferences - had family connections with Theosophy. ${ }^{15}$

The purpose therefore of this article is twofold; on the one hand it seeks to attempt to redress the more general scholarly imbalance by seeking, through a reading of the published conference proceedings, to explore the historical development of the New Ideals conferences. It will do this by offering some context as to their founding, considering their goals, the diversity of their membership, how their priorities shifted during the early years of their activity (a direct result of the First World War) and finally what contribution they can be said to have made to the concretization of progressive ideas which R.J.W. Selleck (amongst others) believed had, by 1939 , become recognised in Britain as state orthodoxy. ${ }^{16}$ Second, it is hoped that implicit within the discussion will be evidence both of the power of specific networks (in this case the New Ideals conferences) to transmit and disseminate ideas but also how this group embodied aspects of conciliation and compromise in its approach rather than being hostile or antagonistic toward authority. In so doing, they can thus be seen to embody that particular typology of cultural movements established by Raymond Williams - and identified by Brehony in relation to the NEF - in which he distinguished 'alternative from oppositional', ${ }^{17}$ that is to say not as seeking to overturn the existing system but rather as content to proffer an alternative vision within its parameters. By drawing such parallels, the paper will therefore bear some similarities with that previous important work of Brehony

\footnotetext{
${ }^{14}$ Maria Montessori joined in 1899. Although her membership would lapse, she would later sit out the Second World War as an 'enemy alien' in the Headquarters of the International Theosophical Society in Madras.

${ }^{15}$ Victor Bulwer-Lytton, $2^{\text {nd }}$ Earl of Lytton K.G. $(1876$ - 1947) was a British politician and colonial administrator. Aside from his interest in education, he had a life-long passion for India becoming Governor of Bengal in 1922. His grandfather, the novelist Sir Edward George Bulwer-Lytton (1803-1873) had an interest in the esoteric with his works much cited by Theosophists whilst at least two of his five siblings were members of the Theosophical Society.

${ }^{16}$ See R.J.W. Selleck (1972), op., cit.

${ }^{17}$ Kevin J. Brehony, (2004), Loc., cit., 743.
} 
whose discussion of the NEF sought not just to understand its strategies but also its interconnectedness with other organizations and creeds, in particular those of the Theosophists. To support its main substantive component, the paper will draw upon those records pertaining to both the early and final three conferences and purposely eschew any examination of the New Ideals Quarterly both for reasons of manageability but also as its quarterly journal format is not really comparable with the one-off verbatim transcripts of conference papers. An exploration of this journal, and how it propagated the message of the movement, will instead form the basis of a subsequent piece of work.

In understanding that the New Ideals meetings were intimately connected to other intellectual movements and gatherings, it is possible therefore to characterise this period as the 'Age of the Conference' and undoubtedly they enshrined a belief in the importance of shared practice and the dissemination of ideas through personal contact and debate. Underpinning these interactions was, however, the New Ideal's espoused belief in 'the creation in the school of an atmosphere of freedom, in which the self-expression of [children's] individuality [can] have as free play as possible', ${ }^{18}$ and it was this broad ethos which, as we shall see, was to be the driving force behind many of their resolutions and choices of themes to be addressed. It is therefore to the founding of this faith that we turn first.

\section{The Montessori Conference of 1914}

The origins of the New Ideals conferences lay in the initial meeting of the Montessori Society of Great Britain, which occurred in the small Norfolk village of East Runton, 25th-29th July, 1914. Such a naturalistic setting whose little community still relied on fishing and farming as a means of subsistence was, in many ways, wholly appropriate as it symbolised a system of education that sought to promote freedom in the classroom and allow for the natural and

\footnotetext{
${ }^{18}$ The Earl of Lytton, 'Presidential Address' in New Ideals in Education: 4th Conference Papers (London: New Ideals Committee, 1917), 2.
} 
unimpeded development of the child. More practically, however, the village also served as the home of Bertram Hawker (1868-1952), an Anglican clergyman who had opened up the first Montessori school in the United Kingdom, which operated from a room in his house and that catered initially for a mere dozen children. Hawker had been inspired by a visit to Rome and, according to Sheila Radice, had 'missed ship after ship [and] stayed in Rome month after month ${ }^{19}$ in order to observe the newly opened casa dei bambini. Nor was Hawker the only one drawn to Italy at this time intrigued by the ideas of La Dotoressa. Following his recent retirement from the Board of Education, the former Chief Inspector of Elementary Schools Edmond Holmes (1850-1936) had also been sent by his superiors to report on the new phenomenon, a visit which was to yield his 1912 pamphlet The Montessori System, which was published as one of the Board's periodic missives. Sol Cohen has pointed out that 'It was Holmes more than anyone else who brought the Montessori Method to England', ${ }^{20}$ and more so perhaps than the practical Hawker - he was especially drawn to the ideological freedoms within this embryonic system, which served to counteract what he saw as the overriding and nefarious philosophy of 'mechanical obedience ${ }^{21}$ within schools. Holmes' own particular interpretation of her work placed then a strong emphasis upon the autonomy it afforded for the child to develop naturally: 'what [Montessori] proved was that self-education is the beginning and end of education - that the business of growing... must be done by the growing child, and cannot be done for him by his teacher., 22

This is an important point to note as subsequent writers and thinkers - including most pointedly A.S. Neill - were to make reference to the didactic aspects of Montessori, in particular her Apparatus, which was seen as overly rigid requiring children, as it did, to

\footnotetext{
${ }^{19}$ Sheila Radice, The New Children: Talks with Dr. Maria Montessori, (London: Hodder \& Stoughton, 1920$), 4$.

${ }^{20}$ Sol Cohen, 'The Montessori Movement in England, 1911-1952' in History of Education vol 3, number 1, (1972), 3.

${ }^{21}$ Edmond Holmes, What Is and What Might Be, (London: Constable, 1911), 3.

${ }^{22}$ Edmond Holmes, 'Introduction' to A Montessori Mother, (London: Constable, 1913), xx.
} 
complete pre-determined tasks. Holmes, however, saw in her schools - as well as that run by Harriet Finlay-Johnson in Sompting - a perfect embodiment of education that was both natural and yet modern in that it cultivated innate instincts but was also prepared to embrace evolving ideas around psychology and child development. This admiration became manifest more practically as Holmes formed part of a committee - which also included Hawker, Albert Mansbridge, Michael Sadler and Lord Lytton - that moved to set up what became known as the English Montessori Society. Kevin Brehony amongst others has charted the development of this organization, which was founded to not merely promote Montessori's ideas to a wider audience but also to contribute to the training and development of teachers and prospective practitioners. ${ }^{23}$ The purpose of the East Runton conference was, then, a way of explicitly meeting the first of these criteria; however, its informal nature - it was held in a barn with children working in neighbouring Montessori classrooms - also meant that it placed a strong emphasis too upon reflective practice with the sharing of ideas and the building up of informal practitioner networks. This was similarly mirrored in the composition of the 250 attendees, 50 of whom were Montessori Society members with the rest consisting largely of interested and curious teachers from around the country. Of the nine published presentations, most reflected the need to be experimental within the classroom space with a particular emphasis upon educating the whole child. Emphasizing a theme that was to find echo in many of the subsequent meetings, this notion was best embodied in a talk given by Lillian de Lissa who spoke of the need for an education to, 'develop him [the child] as an individual, as a personality, things that will prepare him for life and citizenship, these are equally important. 24

\footnotetext{
${ }^{23}$ See Kevin J. Brehony "'Individual Work": Montessori and English Education Policy 1909-1939' (1994) Paper presented at the annual meeting of the American Educational Research Association, New Orleans, LA. ${ }^{24}$ Lillian de Lissa, 'The Social Aspect of Montessori Work' in Report of the Montessori Conference (London: Montessori Society, 1914), 11.
} 
However, whilst this informal and relaxed arrangement was to be a feature of nearly all of the later conferences this was to be the only time in which these gatherings were exclusively Montessorian and the New Ideals conferences were set to encompass a much broader church of opinion. Mention has already been made of Holmes' equal admiration for the work of Finlay-Johnson and this is indicative of the way in which for those of his cast of mind it was both possible and, in fact, desirable to seemingly yoke together various sets of teaching practices and ideologies in order to conceive of a more general philosophy concerned with child freedom. This attitude was reinforced by the variety of topics addressed; although labouring under the banner of the Montessori Society, two long papers were delivered which compared her work to that of Froebel, whilst the most remarkable oration was given by Homer Lane, who elaborated for the first time upon the experiment he had been hitherto performing with juvenile delinquents at the Little Commonwealth in Dorset. As Lane's biographer W. David Wills makes clear, 'it seems unlikely that the relatively cold, scientific, academic personality of the Italian woman can have appealed to him, ${ }^{25}$ and this ideological clash between the scientific Montessori and the more anarchic Lane (whose influences, like those of his disciple Neill, were as much Freudian as anything else) further indicates the heterogeneity of opinions present.

Although Lane was by now well down his own path, Holmes' desire to construct a more allembracing system had its origins both in his recent formulation of the concept of dogmatism ${ }^{26}$ but also the way in which Montessori seemed to have paid insufficient attention to children's creativity, especially when compared to those earlier Romantics such as Pestalozzi whose approaches to education were seen as imbuing children with a more fulsome self-expression

\footnotetext{
${ }^{25}$ W. David Wills, Homer Lane, a Biography (London: Allen \& Unwin, 1964), 124.

${ }^{26}$ This term formed a substantial part of Holmes near contemporary work The Tragedy of Education (London: Constable, 1913). In this book he used it to explain those educational processes by which the child was routinely instructed in his activities and thoughts by the teacher. Although found within many aspects of society, it was particularly prevalent in schools due to the controlling and binding effects of the curriculum.
} 
unfettered by the demands of a 'Method'. Indeed, the problems associated with (specifically) the Apparatus were voiced at this first conference by Clara Grant - Head teacher of Stepney School - who was to comment on its feasibility, especially for those schools, (like hers) which could not always obtain all of the necessary equipment. In comparing her own pupils with those at East Runton she is recorded as saying, 'It was not much encouragement to see at Runton small children under ideal conditions, while they [hers], loving the system, had neither material or apparatus. ${ }^{, 27}$ Given that Grant was herself broadly sympathetic to Montessori's principles, her point about the practicality of such a system carried greater resonance and was to be later reflected by those such as Margaret McMillan who were similarly struggling to engage students in the context of poorer and more deprived communities. Nor was Grant's critique any the less powerful for it having been delivered spontaneously and therefore 'unedited' for the benefit of the audience, many of whom were committed devotees of the Italian's ideas. Hence it was clear, almost before any attempts had been made, that incorporating Montessori's Method (if not her general philosophy) with the ideas of many other nascent progressives into a set of educational principles and maxims acceptable to all would be a nigh-on impossible task. This was particularly the case given the resurgence of alternative sources of progressive educational succour: Joachim Liebschner for one has charted the concurrent rise of the British Froebelian Society ${ }^{28}$ whilst the continuing popularization of the works of Rudolf Steiner was to lead in 1925 to the founding of Michael Hall School.

Although, then, this was clearly a conference celebrating the freedom of the child, this freedom took many forms and was necessarily not to be associated with one faction or group. To that end, a resolution following this meeting stated that a committee be formed 'with the

\footnotetext{
${ }^{27}$ Clara Grant quoted in de Lissa, loc. cit., 24.

${ }^{28}$ See Joachim Liebschner, Foundations of Progressive Education: The History of the National Froebel Society, (Cambridge: Lutterworth Press).
} 
object of repeating the conference, and that to it should come not only representatives of the Montessori movement but of kindred movements. ${ }^{29}$ Whilst this ideal was taken by most as an opportunity for further discussion, as Rita Kramer has mentioned, 'This was precisely what Montessori did not want - to have her method and the movement on its behalf blend in with other theories and systems. ${ }^{30}$ With such a threat to its sovereignty, the Montessori Society committee therefore disbanded and, then, re-formed, this time with the previously supportive Montessori herself as the President. Although some of its members returned the following year to present papers, in none of the ten subsequent New Ideals conferences was the name of Montessori mentioned in this way again. This was not out of any sense of personal spite or residual antipathy but more as it embodied what was to be one of the great legacies of New Ideals thinking - stemming from Holmes - which was the avoidance of factionalism, dogma and any tendency toward partiality. Evincing too the optimism inherent within this new era of education, and concurrent with political and administrative changes to its structure, ${ }^{31}$ these subsequent conferences, although underpinned by the need to remove the traditional authority of the teacher, were very much about questing for a set of organic values and practices by which this could be achieved.

\section{General Philosophy and Attendance at the Conferences 1915 - 1923}

In its early years, and with the exception of 1920, conferences were held annually between 1915 and 1923. Throughout this time, numbers of participants rose steadily and came eventually to include some whose business was not solely - if at all - education. We are fortunate in that appended to the presentation transcripts are complete lists of those attending

\footnotetext{
${ }^{29}$ Quoted in Olive Smee, 'The Montessori Apparatus and its Use' in Report of the Montessori Conference (1914), 165 , italics added.

${ }^{30}$ Rita Kramer, Maria Montessori: A Biography, (Oxford: Blackwell, 1978), 243.

${ }^{31}$ These included greater provision for secondary education following the 1902 Education Act as well as the raising of the school leaving age to 14 and the expansion of continuation schools as a result of the 1918 Education Act.
} 
(including initially their address and occupation), which allows us to get a better understanding of the meetings' demographics. As an example, the records from 1918 show a total attendance of 368 delegates of whom 57 were men and 311 women. We also find that they came from all over the United Kingdom including places as distant as Edinburgh, Durham, Cornwall and Eastbourne. Such lists are valuable then as they provide firm evidence for the way in which interest and engagement with these new ideas were neither limited to certain areas of the country nor for that matter to a particular type of school. They also encompassed those from different areas of educational practice and included disproportionately large numbers of women, testament perhaps to their emergent agency in spreading the latest educational ideas.

Put simply, these were not events put on casually to pique the interest of classroom teachers, and the cross-section represented here includes school inspectors, politicians associated with various education committees as well as those senior figures within educational management and pressure group organizations. ${ }^{32}$ This is indicative of the way in which the New Ideals gatherings - which as we have mentioned were far from being stubborn and oppositional sought to disseminate their ideas by intentionally cultivating those in authority. Whilst in part this reflected the Establishment background and connections of those such as Lytton and Holmes, it also embodied an aspect of this group's philosophy, which was to be as inclusive as possible in transmitting its ideology. This was reinforced by the way in which there was a clear mandate on the part of the Committee to reach as wide an audience as possible through publication of its proceedings; to that end, it is noted by 1916 that through the generosity of

\footnotetext{
${ }^{32}$ As an example, in 1918 attendees included Miss C.M. Brown, Secretary to the Civic and Moral League, the famed publisher J.M. Dent, Mr. J. Reeves, a School Inspector, Captain A. St. John from the Penal Reform League as well as numerous Principals and Head teachers.
} 
an anonymous benefactor, 'any teacher in an Elementary school can receive a free copy by sending name and address on a post-card to the Secretary. ${ }^{, 33}$

As a consequence of this, and when attempting to understand the essence of these conferences, the immediate thing to note is that the New Ideals grouping saw itself as far more closely connected to educational practice than it did of being any form of social, spiritual or even political movement. This understanding was made explicit in the group's early attempt to define its 'definite objects of policy' ${ }^{34}$ which were, respectively, to 'Utilise the period between the successive Conferences in looking out in the country for experiments in education, practical experiments...in conformity with our ideals' ${ }^{35}$ and, second, to 'select in each year one prominent subject of immediate and special interest...to concentrate upon. ${ }^{36}$ This agreed statement of aims is worth dwelling on for an instant as it stands in contrast to the thinking of the NEF, which 'bore little relation to the notion of education as a science or experimental education as conceived by the positivists, who dominated the embryonic academy. ${ }^{37}$ One can therefore surmise from this why there existed such a considerable overlap in personnel and membership between the various groups and how they can be seen as mutually supportive of one another. If the focus of the NEF for example was more internationalist and concerned with adumbrating philosophical notions of the world citizen and wider rights of the child, then the New Ideals' emphasis in contrast was upon ways to encourage that within the classroom. Likewise, the Theosophical Movement, spurred in part by the recent publication of Krishnamurti's Education as Service in 1912, decided to explore the ways in which their esoteric ideas could enmesh with the classroom and therefore made

\footnotetext{
${ }^{33}$ 'Introductory' in New Ideals in Education: 3rd Conference Papers, vii.

${ }^{34}$ The Earl of Lytton, loc., cit. (1917), 4.

${ }^{35}$ Ibid.

${ }^{36}$ Ibid.

${ }^{37}$ Kevin J. Brehony, (2004) loc.cit., 742.
} 
conscious efforts, 'to get interested Theosophist teachers to join the annual education conferences centred around Edmond Holmes. ${ }^{38}$

This conception of the New Ideals group as therefore being complimentary to its bedfellows through its endeavours to emphasise practice needs also to be understood in light of the apparent aforementioned rejection by the NEF of teaching as a science. As Adrian Wooldrich has rightly indicated, much of the preliminary work of the child-study movement and, in a more sophisticated manner, that of early psychologists was indeed concerned with the need to formulate and test hypothesises with a view to searching for a science of teaching guided by a set of underlying generalizable laws and rules. ${ }^{39}$ However, whilst it is true that this notion seems to stand in opposition to the New Ideals' apparent rejection of the Montessori approach - which very much believed it had cracked the code to progressive teaching through its development of a scientific method - the key to understanding its philosophy is surely through its embodiment of what today would be called praxis, that is the meaningful integration of theory and practice with 'truth' being found in the crucible of actual experience. In that vein, papers at the 1916 conference addressed topics as diverse as ethical issues in religious education and the role of handicraft in schools, as well as the benefits of open air schooling. Likewise, 1917 saw a full day of presentations - specifically titled Experiments Day - devoted to developing a 'clearing-house for educational ideas and experiences...not with a view to its being slavishly imitated, but with a view to its being studied and meditated on, and becoming a source of inspiration. ${ }^{40}$

Ultimately, much of the desire to invoke practice in this way can be put down to the intellectual alliance of Holmes and Lytton who were to be the driving forces behind these

\footnotetext{
${ }^{38}$ M.D. Lawson, (1981), loc., cit., 24.

${ }^{39}$ See Adrian Wooldrich, Measuring the Mind: Education and Psychology in England, c.1860-c.1990, (Cambridge: Cambridge University Press, 1994).

${ }^{40}$ Edmond Holmes, 'Experiments Day' in New Ideals in Education: 4th Conference Papers (1917), 85-86.
} 
gatherings. Holmes had previously been a School Inspector of thirty-six years ${ }^{41}$ and his observations in a range of districts had rendered visible the many deep and inherent flaws within the system, in particular the prevailing need, as he saw it, for the teacher to constantly be instructing the pupil as to what to do and how to do it in a way that was both rigid and mechanical. He had laid down this position in his seminal and popular work What is and What Might Be (1911), ${ }^{42}$ composed for the most part whilst still in the employ of Whitehall, and whose two parts as delineated by the book's title provided both a diagnosis and solution to the prevailing problem. The latter resided in some of the more forward-thinking yet still fundamentally practical establishments he had observed, notably the aforementioned Sompting run by Harriet Finlay-Johnson in which the use of Drama was so prevalent. Latterly as both a Divisional Inspector and then Chief Inspector of Elementary Schools he had similarly made a conscious effort to promote the spreading of these practices, particularly through his endeavours to set up a network of training colleges for teachers. By the same token, Lytton had already shown his engagement with a range of radical causes including women's suffrage, the garden cities movement and boys' clubs, the latter of which were attempts to bring rurality and 'nature' into the lives of urban children - a theme as we shall see that was to be important within the New Ideals movement. In further coming under the influence of Homer Lane in 1913, which involved not only giving his support to the Little Commonwealth but also engaging in private counselling sessions, Lytton too was to demonstrate an understanding of education that was as much concrete as ideological.

In extending non-partisanship to encompass a lack of explicit politicking in this way meant that the New Ideals group were less concerned with yoking educational ideas to wider

\footnotetext{
${ }^{41}$ Holmes had been an Inspector in the West Riding District (1875 - 1879), the Ashford District in Kent (18791897) as well as Oxford (1897-1903). Following a brief period as Divisional Inspector in Northumberland he was appointed Chief Inspector of Elementary Schools in 1905 where he remained until retirement in 1910. ${ }^{42}$ What is and What Might Be: A Study Of Education in General and Elementary Education in Particular (London: Constable, 1911)
} 
political notions and ideas (often Continental) around freedom or in seeking to embroil pedagogic thinking with more abstract elements of social theory such as Marxism. ${ }^{43}$ This meant, more significantly, that the doors of this broad church were open to those from across the political spectrum. Lytton for example was both a Conservative (albeit an unorthodox one) and an hereditary Peer whilst those other attendees such as Robert Baden-Powell and Henry Newbolt were to be popularly associated with the exigencies of Empire and a certain sort of Edwardian Englishness bordering on the jingoistic. ${ }^{44}$ By being so inclusive, the New Ideals gatherings were, then, not seeking to embody or enact the language of protest by attempting to over-turn the existing educational system or its fundamental structures. Instead, theirs was the modified voice of adaptation personified best in the appeal to delegates made by H.A.L. Fisher: ${ }^{45}$ 'we want a great army of missionaries, and I would ask every one of you here who is anxious to secure an advance in education to influence so far as you possibly can those people with whom you come into contact and who may want a little gentle or strenuous conversion. ${ }^{46}$ This sentiment - given by one in close proximity to the higher echelons of power - was very much in keeping with the ideas of Holmes, whose own relationship to politics and 'democracy' was complex and defied straightforward characterization. Indicative of this was his anecdote about the former pupil of Sompting School who having completed his education, 'found employment in a large field on the lower slopes of the hills, where he had to collect flints and pile them in heaps...But he found the work neither dull nor tiresome;

\footnotetext{
${ }^{43}$ As Boyd and Rawson in The Story of the New Education (London: Heinemann, 1965) have shown, this was also the case for the New Education Fellowship who similarly embraced a wide range of intellectual and political positions. This involved not merely individual Marxists attending but also some Nazis in the early days of the Third Reich!

${ }^{44}$ The poet Henry Newbolt (1862 - 1938) had been employed by interwar governments on matters associated with English teaching, most famously in the Newbolt Report of 1921. His well-known poem Vitai Lampada with its refrain of 'Play up! play up! and play the game!' came to be seen as emblematic of the esprit de corps and service that characterised a certain facet of Empire. Similarly, Baden-Powell's Scout movement with its penchant for uniforms, allegiance to Monarchy and its emphasis upon drill carried militaristic overtones. ${ }^{45}$ Herbert Albert Laurens Fisher $(1865$ - 1940) was a Liberal politician who served as President of the Board of Education in the Lloyd George Coalition Government from 1916-1922.

${ }^{46}$ H.A.L. Fisher 'Inaugural Address on Continued Education' in New Ideals in Education: 4th Conference Papers (1917), 15.
} 
for [as] he marched up and down the field, collecting and piling the flints with cheery goodwill. $^{, 47}$

After that fashion, Holmes was as distrustful of the doctrines of the left as of the right and, in that spirit, although opposed to much of what passed for educational orthodoxy (in particular the use of rigid mental measurement and testing), the members of the New Ideals gatherings were content initially to proffer an alternative vision of education, often within a context of individual experimentation conducted outside of the auspices of established dogma. In part, this reflected enduring political moves, noted best by Roy Lowe, in which Whitehall had ceased to be as stringent in directing the activities of teachers. ${ }^{48}$ It also pre-empted another emergent trend, which was toward the foundation and development of autonomous private communities. Although this was to reach full fruition in the decade after the war with the founding of such influential establishments as Summerhill, Tiptree Hall and Beacon Hill, it is worth noting that the 1916 conference saw talks delivered by both John Arrowsmith (of Mixenden) and Phyllis Potter, director of the Caldecott Community. In the course of surveying her establishment's history and in accordance with the New Ideals vision, Potter in particular was quick to make the point that, 'We could tell you what out theories were three years ago, but we cannot say what they will be tomorrow, nor dogmatise on our methods of today. ${ }^{49}$ Deriving from their origins within the Montessori Society, whose own reputation had been forged thanks to the interest generated by its schools in Rome, the New Ideals group then was to both actively support and encourage such work as was being done within these types of institutions, many of which were to trial and develop radical practices and experiments in democracy.

\footnotetext{
${ }^{47}$ Edmond Holmes op. cit., (1911), 193.

${ }^{48}$ See Roy Lowe, The Death of Progressive Education: How Teachers Lost Control of the Classroom, (London: Routledge, 2007).

${ }^{49}$ Phyllis M. Potter, 'The Caldecott Community: A Study in Temperaments' in in New Ideals in Education: 3rd Conference Papers, 187.
} 
Despite this championing, what is equally noteworthy about the conferences was that they were clear not to overlook those more small-scale initiatives designed and developed by teachers within more 'mainstream' education and at all of the meetings there were to be papers delivered by active classroom practitioners. Although more humble in scope, these were to be seen as equally important in furthering the group's aforementioned belief in celebrating examples of innovation. Typical of this mix would be the 1922 conference, whose theme of Drama in the Curriculum placed the heavyweight Rudolf Steiner on the same platform as a host of school drama teachers - in this case a Miss F.C. Beaumont, Guy Pocock and Elsie Fogerty. In thereby choosing to downplay or give comparatively short shrift to the New Ideals conferences, traditional historical narratives detailing the dissemination and development of progressive ideas and progressivism have often narrowed their scope to focus exclusively on those more obviously unorthodox or better-known individuals and institutions. Whilst of course correct to acknowledge their importance, an analysis of the New Ideals conferences would appear to indicate that interest and engagement with 'new' or 'progressive' ideas around education percolated much deeper than just the more celebrated figures and that many mainstream teachers were equally prepared to act innovatively and of their own volition.

The democracy which formed such an essential part of these ideas was thereby neatly reflected in access and transmission; this was not to be a movement bound to tracts, rules or, as had been found with Montessori, a system to be religiously worked through. Although it would be inaccurate to contend that all who attended were receptive or supportive of everything they heard, it is enough to say that the New Ideals conferences acted as a conduit and melting pot of new ideas and, unlike the NEF, was unencumbered by the need for members to formally subscribe. This in turn generated professional confidence and proffered encouragement in those attending the meetings but also, through avoiding the desire to 
become explicitly political, meant the gatherings did not suffer the constraints and tethers of ideological dogma. Such schisms were to later permeate both the NEF, the Froebelians and, in the most well-known example, the Montessori Movement, which divided over the need, or not, to stringently follow the creeds and pronouncements of its founder.

If, however, this variety of presentations on show was driven by one of the fundamental planks of the movement, which was the encouragement of diverse practice and experiment, it should not be to assume that there was no wider collective point of agreement. In fact, what united and underpinned many of these efforts was a notion of which all members would surely have approved, notably the fundamental right to liberty and freedom for the child in the classroom setting. The term 'freedom' has in progressive discourse been overlain with a range of meanings and interpretations, a point well illustrated by the discussions at the 1923 conference whose theme of The Discipline of Freedom was to allow for some of these nuances to come to the fore, in particular questions over the relationship between freedom and licence. This distinction is therefore important to understand, for the overall position of the New Ideals group was one that, whilst in favour of freedom from injurious constraint, certainly did not advocate freedom from any form of limitation whatsoever. Freedom and discipline were not to be thought of as diametrically opposed concepts.

Although this sounds a comparatively 'weak' or negative form of freedom - and somewhat against the populist reputation many of these schools have since acquired as hot-houses of anything-goes radicalism, it nonetheless encapsulated the New Ideals approach, which was one driven less by explicitly political or indeed social considerations of liberty and more by freedom of the spirit, an understanding, as we shall shortly see, given impetus by wider global events. Whilst such spiritual freedom was to be encouraged, it could only be fully developed when the child had acquired an understanding and appreciation of discipline. This was not of course the discipline of mechanical obedience or classroom sanctions but, instead, 
self-control in which children became masters over their own learning and therefore innately appreciative of the need to be obeisant of laws and regulation. This formulation was best articulated in a paper at the 1923 conference given by a Miss Mackinder: 'The happiest people I have met are those who are most rigidly obedient to laws, because they want to be obedient to them... Our desire for freedom for our children exists because we want to make children in love with law. ${ }^{50}$

Mackinder's argument was one that typically echoed those thoughts of Holmes, whose sympathy with Buddhist ideals (he had earlier penned a well-received critical appreciation of Buddhism $^{51}$ ) demanded an interrogation and disciplining of the Self free from materialistic impulses. Although his particular understanding was in that regard somewhat idiosyncratic, it nevertheless reflected more widely an understanding of liberty that was not to come simply from allowing children to do as they desired thereby giving prominence to the physical or carnal impulse but, rather, as encouraging spiritual and psychological freedom 'which is the kind of freedom in the long run most worth having. ${ }^{52}$ Whilst there were always questions to be posed as to the input of the teacher - another earlier sticking point in relation to Montessori - essentially the New Ideals movement was as one in believing that the highest form of liberation for children would come not merely when they were allowed to pursue their own interests and endeavours but when they were equally conscious of themselves as free learners. As L.P. Jacks was to state, 'whether or no (sic) a man is free, does not depend on any philosophy or theory which he or anybody else may hold on the matter. It depends on his own action. ${ }^{53}$ True freedom was not therefore to be something merely given or bequeathed by the benevolence of the adult but, rather, stemming from the activities and

\footnotetext{
${ }^{50}$ Miss Mackinder, 'Freedom for Young Children' in New Ideals in Education: 9th Conference Papers (London: New Ideals Committee, 1923), 66.

${ }^{51}$ This was The Creed of Buddha, (John Lane: The Bodley Head, 1908).

${ }^{52}$ J.H. Simpson, 'Freedom and Adolescence' in New Ideals in Education: 9th Conference Papers (1923), 84.

${ }^{53}$ L.P. Jacks, 'Inaugural Address' in Ibid., 23.
} 
understanding of the child as it became a fully self-realised being, liberated in its choice of activity and thought. Whilst this may not have been the language used or understood by many of the conference delegates who, as teachers, were more concerned with aspects of practice, there remained a prevailing and conscious understanding that - foregoing disagreements over method or aim - children had the right to be responsible for the shape and direction of their learning.

\section{Impact of the First World War}

It is important to remember when considering the early New Ideals conferences that they took place under the continuing shadow of the Great War - a factor which was to shape not merely the substantive content of the meetings but also the overall philosophy and direction of the movement. Appropriately, the 1914 East Runton gathering had concluded its business on the $28^{\text {th }}$ July, exactly one week prior to the official British declaration of war on Germany. This was appropriate, for, as the world entered a new turbulent age of shifting alliances, warfare and brutal mechanization, so the by now all-encompassing New Ideals community begun to embody the quest for a different understanding of education driven not by dogma, homogeneity or prescription but by individuality, investigation and the sharing of original practice. These wider events - and the apparent failing of long-established social and political systems to prevent conflict - meant that the world at large was at a 'tipping point' and, as a result, it had created an intellectual vacuum in which a contestation of values and debates over the place and primacy of new ideas was taking place. This was clearly manifest within the other art forms in which fresh sounds such as had been pioneered by Stravinsky and Schoenberg caused a rethinking of the possibilities of tonality whilst, in painting, those movements such as the Futurists, Vorticists and Cubists captured something of this implosion by pioneering new and often explosive articulations of form and vision. Paralleling these developments, and particularly given the rise of growing insights offered by science and 
psychology, education appeared to be little different and the New Ideals group fitted very much into this emergent context in which the established centre had clearly failed to hold.

This position was best articulated by a Mrs. Hutchinson (from Catherine Street LCC school) whose 1915 paper on Montessori in the elementary school nonetheless still managed to speak to those wider concerns: "The problem is not then "shall we continue to educate?" but "shall we continue to educate upon our present system?" What shall our children be taught, and how shall this education be carried out? ${ }^{, 54}$ The war - which caused such a 'mental upheaval' many - served then as an important influence in inflecting the conferences with a particular mind-set of inquisitiveness and a desire to evolve sets of values to serve as a blueprint for uncertain times. One of the New Ideals' oft-repeated mantras as laid down in its 1916 conference had been to "work [together] upon the basis of a common conviction that a new spirit, full of hope for the world, is stirring in education ${ }^{, 56}$ and, although in one sense this ambition was deliberately vague so as to aid the pragmatic end of not narrowing the group's appeal, it also served to reflect a deep-seated and underlying set of beliefs founded upon the need to engage with new developments and understandings from within a wide range of fields and intellectual positions. This became equally manifest through the linkages established with those other groups; in particular, the spiritual elements of Theosophy, which were of interest to some in the New Ideals camp, were understood as one way in which to, 'unite in fellowship all who are interested in the spreading of the New Ideals in Education which the spirit of the new age is demanding., 57

\footnotetext{
${ }^{54}$ Hutchinson, 'The Montessori Principle in the Elementary School' in New Ideals in Education: 2nd Conference Papers (London: New Ideals Committee, 1915), 84.

${ }^{55}$ Ibid.

56'Introductory' in New Ideals in Education: 3rd Conference Papers (1916), vi.

${ }^{57}$ Beatrice de Normann, Brotherhood and Education, (London: Theosophical society in Education, 1917), 19 quoted in Sue Middleton, op., cit., 4.
} 
Indeed, the fact of the subsequent meetings even taking place at all during such a national emergency with its attendant privations was one that continued to receive explicit recognition by the participants, including Lytton, who bullishly asserted that continuing to meet was 'the result of a deliberate decision of the Committee. They believed that the holding of the conference was not only consistent with what was in everybody's mind, but was a duty rendered even more necessary by the fact that the country was at war. ${ }^{58}$ This determination was driven by a conviction that whilst there were as yet no cast-iron certainties as to a solution, it was the 'old' system of education which was seen as culpable for the sorts of events currently scarring the globe. Furthermore, it was previous assumptions around education, including the often-subservient position of the child in relation to the teacher and the attendant materialism within a system fostering competition, that were now seen as wanting.

In that vein, the first full paper of the war-time conferences in 1915, and one which set the later tone, was delivered by Holmes in which he compared the British and German ideals of education. Although suitably patriotic and a year later to form the basis of a substantial book, ${ }^{59}$ his attack on Germany shunned those more superficial contemporary critiques which chose to focus explicitly, often in nationalistic terms, on recent and demonstrable political militarism or economic imperialism. Instead the microscope fell upon that country's system of education, which was seen as enacting, within the context of its schools, many of the worst aspects of obedience, unthinking action and automatism: 'In Germany...the pressure of autocratic authority on life is constant and strong... There are three things which it necessarily does...to all who come under its influence: (1) To mechanicalise life. (2) To externalise life.

\footnotetext{
${ }^{58}$ The Earl of Lytton, 'New Ideals in Education' in New Ideals in Education: 2nd Conference Papers (1915), 1.

${ }^{59}$ This was The Nemesis of Docility: a Study of the German Character (London: Constable \& Company Ltd., 1916)
} 
(3) To weaken the will, which is the mainspring of life. ${ }^{, 60}$ The contrast made with England was significant as this represented a deliberate attempt by Holmes, and by extension the New Ideals movement, to yoke wider social failings and misdeeds - including the supposed atrocities associated with Arthur Marwick's Total War ${ }^{61}$ - to the practices and dogmas of the classroom. The choice here of the all-pervading term 'mechanical', although deriving from earlier on in his oeuvre, was especially appropriate given how it carried dual associations with both soldiery and militarism but also passive classroom obedience. This was a failing manifest not simply through unthinking action but also the way in which this docility was seen as contributory to German mechanization, belligerence and militarism. Such metaphors and overtones undoubtedly sharpened the resolve and gave urgency to the New Ideals delegates. More importantly, however, in expounding upon the Germans' misguided Hegelian devotion to the State, it served notice to those in authority of the necessity of devolving power away from the centre and, instead, into the teacher's personal fiefdom of the classroom.

Much of that autonomy was ultimately to be reflected in encouraging the sort of experimentation discussed earlier on; however, the broader question as to how to 'go far towards making such catastrophes impossible ${ }^{, 62}$ was one which was to shape the agenda of those conferences immediately following the cessation of hostilities. One can thus identify a discernible shift in the tone of the meetings from those held between 1915 to 1918 , which were more concerned with simply putting forward and displaying practice, to those from 1919 to 1923 in which such practices became connected to wider concerns and questions over the pressing need for reconstruction: 'The old world is dead and the new world is at school.

\footnotetext{
${ }^{60}$ Edmond Holmes, 'Ideals of Life and Education - German and English' in New Ideals in Education: $2^{\text {nd }}$ Conference Papers (1915), 10.

${ }^{61}$ See Arthur Marwick (Ed) Total War and Social Change, (Basingstoke: Macmillan, 1988).

${ }^{62}$ Bertram Hawker, 'Introductory Address' in New Ideals in Education: 6th Conference Papers (London: New Ideals Committee, 1919), 2.
} 
In between the two are the armies who have bled and suffered for the errors of the old. They all call for...new ideals in the school., ${ }^{, 63}$

Significantly, then, the 1919 conference was on the broad theme of creativity, an issue addressed still further in 1922 in which Drama in Education served as the chief focus. These choices of subject clearly indicated the incumbent view that no longer were these childish impulses to be creative worthy of encouragement merely out of sympathy with the need to allow the child to experience the palliative outdoors or to fulfil those psychological instincts which Holmes had earlier spoken about. Nor was this to be an opportunity simply to showcase innovative practice. Instead, such activities were understood to serve a more profound need, one made most evident in a paper delivered by Arthur Brock whose work as doctor with shell-shock victims at Craiglockhart Hospital had included the poet Wilfred Owen and which had been driven by the desire to aid his patients' recovery with arts and crafts activities. For Brock, the condition of his patients - whom he described as 'separated from the world about [him], - either he does not see it, or he takes no interest in it ${ }^{64}$ - paralleled that of pre-war school children in both their docility and powerlessness in the face an oppression created by newly industrial society, in this case shells and weaponry. This, then, was important in that it starkly reflected - through a topical reference to contemporary events - the centrality of self-directed activity in ensuring mental vitality and independence of thought. Coupled with Holmes' earlier warnings over the docility present within Germany (in which, like Brock's educational/ military comparison, the teacher was to be equated with the drill sergeant) the stunting of creativity and free expression was seen as grievously damaging to society. As Henry Wilson (1919) was to warn, 'Work which is not the expression of spiritual activity is servitude. Servitude degrades both slave and owner. Education in the

\footnotetext{
${ }^{63}$ Henry Wilson, 'Epilogue to the Conference' in New Ideals in Education: 6th Conference Papers (1919), 131.

${ }^{64}$ Arthur Brock, 'The Effect of Handicraft on Mind and Body' in Ibid., 26.
} 
future must be creative education. Only that can kill slavery. ${ }^{, 65}$ When seeking thereby to understand the paradigmatic shift that took place in our conception of the child toward what Hugh Cunningham has called 'children of the nation, ${ }^{66}$ it is surely important not to overlook the response to the War as collectively articulated by this group, especially when it was adults who were represented as the begetters of the destruction: 'we must fit them [children] if we can... for the task of rebuilding the world we have ruined. ${ }^{, 67}$

Brock's paper is also noteworthy as the language of therapy that it used was to be reproduced within several progressive schools which received New Ideals' support. The Little Commonwealth, for example ,was set up as an institution to treat those individuals classed as juvenile delinquents whilst the rural Caldecott Community was similarly designed to compensate those children within deprived inner-city areas by taking them out of urban squalor. It seems that much of the sickness of Mankind (whose general condition was seen to mirror that of shell-shock victims) was only to be treated by a dose of the sorts of values and activities as were being undertaken in those kinds of schools. In considering its response to war it is therefore striking that the tenor of the post-war New Ideals conferences was one falling back on older and more rustic models of education. Brock for example was to state that, 'We must go back to and make our start from the primitive occupations of field and forest, of mountain and sea, ${ }^{68}$ whilst elsewhere Margaret McMillan was to argue for an outdoor education in which children 'may win a spiritual exultation that will draw out all the mental powers, as sunlight deepens and vivifies the colours of the hills and gardens. ${ }^{, 69}$

\footnotetext{
${ }^{65}$ Henry Wilson, 'The Creative Impulse and its Place in Education' in Ibid., 6.

${ }^{66}$ Hugh Cunningham, The Invention of Childhood, (London: BBC Books, 2006), 177.

${ }^{67}$ Henry Wilson, loc., cit., (1919), 5, italics added.

${ }^{68}$ Arthur Brock, 'The Effect of Handicraft on Mind and Body', 47.

${ }^{69}$ Margaret McMillan, 'Freedom of the Open Air' in New Ideals in Education: 9th Conference Papers (1923), 8182.
} 
McMillan's agenda was by this stage of course well known, but the war clearly gave an added impetus to her broadly anti-industrial and neo-Romantic way of thinking and was reflected still further by presentations addressing, amongst other things, needlework, handicraft and acting. Whilst this sense was, once more, to pervade other areas of contemporary artistic endeavour - the writings of Edward Carpenter for example as well as the Arts and Crafts movement, whose key figure T.J. Cobden-Sanderson had previously published Holmes - in education it had been latent in the decades leading up to the war. Holmes himself had described his 'Utopia' - Sompting School - in particularly Arcadian terms:

'It nestles at the foot of a long range of hills; and if you will climb the slope that rises at the back of the village, and look over the level country that you have left behind, you will see in the distance the gleaming waters of one of the many seas that wash our shores. ${ }^{, 70}$

Any sense of anti-industrialism on Holmes' part was deliberate and this Sussex rurality was to be mirrored too in (amongst many others) Norman Macmunn's Tiptree Hall, the Caldecott Community set within the Kentish hills, the Theosophist schools in leafy Letchworth and Brackenhill and the Little Commonwealth which resided in the Dorset countryside. Now, however, these apparent accidents of geography took on more weight as they became appropriated into a more cohesive philosophy envisaged as a response to the destructive effects of war. In many ways, this philosophy served as a curious hybrid; on the one hand seeking a return to a freer and more primitive 'back to Nature' type of education whilst, on the other, doing so by recourse to the latest psychological thinking. Something of this flavour was captured in a paper given by Sir Robert Baden-Powell in which he argued not just for an education following that of his Scouts and their outdoor activities but also a series of values

\footnotetext{
${ }^{70}$ Holmes, What is and What Might Be, 154.
} 
which could be used to create a 'sense of honour' ${ }^{71}$ amongst future leaders of world communities. In therefore acknowledging this unique confluence between the traditional and the cutting-edge, he was to write, 'Then there is the education of the child itself; in this we are going forward all the time. Immense developments have gone on in the last few years. I think this question largely hinges on one little fact, that Instruction is not Education. ${ }^{, 72}$ Given his militaristic and imperial connections it seems extraordinary that Baden-Powell would argue so strongly for the need for such child-centred principles yet his advocacy says much both for the wide appeal and pull exerted by the New Ideals' doctrines as well as the connection between them and the growing consensus around building a better future.

Although the desire to seek to abolish traditional authority in the classroom was one prevalent from the outset even within the Montessori Society, it was reinforced and given fresh impetus by the war which threw into sharper relief the failings of long established systems of schooling. To once more return to Mrs. Hutchinson, 'If the education of Man is to result in speedier and more complete methods of annihilation and enslaving his fellows, then I maintain that education of this kind is a curse. ${ }^{, 73}$ In making such assertions, critiques made by those such as Holmes, which argued stringently for creativity and the abolition of authority, became seen as beneficial not merely for the development of the individual child but also for the wider aspect of society. No longer did the earlier proclamation of Caldwell Cook that what mattered was "not [for] the destination, but [chiefly for] the journey ${ }^{, 74}$ hold sway. Progressivism was becoming equated with, and acquiring the tone of, collectivism and, although the connection between education and the future shape of society was not necessarily new, it was no longer to be thought of merely as a way of providing the most basic of skills or as reinforcing social roles and expectations. Although not politically oriented, the New Ideals' ideas - hastened and

\footnotetext{
${ }^{71}$ Robert Baden-Powell 'The Boy Scout Movement' in New Ideals in Education: 3rd Conference Papers (1916), 61.

${ }^{72}$ Ibid., 57.

${ }^{73}$ Mrs. Hutchinson, loc., cit., (1915), 83.

${ }^{74}$ Henry Caldwell Cook, The Play Way: An Essay in Educational Method (New York: Frederick A. Stokes Company), 8.
} 
made concrete by the war - were those that sought to tie the health and prosperity of the nation to the liberty and, especially, the creativity of the child.

\section{The last three meetings 1935-1937}

Following the conference of 1923 , there was to be a 13-year hiatus before the organizing committee desired any return to publishing their proceedings in the previous manner. Instead, as we have seen, the prior format, which consisted of simply gathering together the verbatim transcripts, was replaced by issues of the New Ideals Quarterly. Whilst providing greater continuity between the annual meetings, it might also have been the rise of the NEF - whose first conference was held in Calais in 1920 - that caused this more professional approach to be adopted. Its magazine the New Era (originally the journal of the Theosophical Fraternity) was by now well established and it might be speculated that the desire of the New Ideals to professionalise owed something to the wide circulation and burgeoning reputation of that publication. Undoubtedly, the format of the journal with a series of shorter articles appeared more approachable than a bundle of conference papers. In itself, this provides more evidence of the connectedness between these two organizations, particularly given their shared readerships and contributors. One such individual who flitted between all these groups was the New Era's first editor Beatrice Ensor, ${ }^{75}$ who, in her capacity as a leading figure within the NEF, was comparable to Holmes and Lytton particularly as her background and connections were of the similarly appropriate sort to foster the wide aims of the organization.

In addition it must not of course be forgotten that by this time the world was a markedly different place having seen global financial disaster, consequent mass unemployment and the rise of Nazism, Stalinism and Fascism. Indeed, by the time of the last of these gatherings that

\footnotetext{
${ }^{75}$ Kevin Brehony op., cit., (1997) outlines these connections particularly well. In particular he cites Ensor who represents a good example of the professional traffic between the three groups as it was she who was one of the initial founders of both the Theosophical Fraternity and the NEF as well as attending the 1914 East Runton Conference. Her views in on education and religion were similar to those of Holmes although they disagreed on the nature of reincarnation.
} 
earlier global conflict which, as we have seen, had done so much to shape the initial thinking of the group, was in danger of itself being repeated, a point that did not go unrecognised amongst the delegates: 'those concerned with education had to meet the new menace of dictators, who dislike above all things democracy, liberty, freedom of expression. ${ }^{76}$ However, whilst this warning was timely, this should not be to suggest that the earlier feeling of optimism had proven unfounded and, in some respects, the ambition of the New Ideals group to call for a change in the relationships and dynamics within the classroom through the liberation of the child had borne fruit. The six Hadow Reports for example - commissioned by the Board of Education and which emerged piecemeal between 1923 and 1933 - said much that would have found favour with the New Ideals delegates in particular their advocacy of "experience and activity rather than facts to be stored. ${ }^{77}$ This was in addition to Hadow's other key commitment to an education for all that was driven broadly by the child's own interests. In a similar vein, the success and rising popularity of the Dalton Plan with its 'assignment system' had called into question more traditional school organizations.

Whilst, however, it may be easy to overestimate their importance, it is surely to the New Ideals gatherings that we must initially look to explain any such success that progressive ideas enjoyed in the inter-war years. Although much of this message was to be sustained by its journal - a factor that will be explored in another article - in part this realization was explicable through that reciprocal relationship, fostered within the very fabric of the early conferences, which sought not just acknowledgement from policy makers for their ideas but also their active involvement. Even the austere Robert Morant - no great friend of the teaching profession as the events surrounding the earlier Holmes-Morant Circular had shown

\footnotetext{
${ }^{76}$ Sir Ernest Simon, 'Education and Democracy' in New Ideals in Education: 22nd Conference Papers (London: New Ideals Committee, 1935), 50.

${ }^{77}$ Hadow Report, The Primary School, (London: HMSO, 1931), 93.
} 
- was recorded as having attended 'for a few tantalising minutes" ${ }^{78}$ and we have likewise already noted the participation of such luminaries as Lytton and H.A.L. Fisher.

What is therefore important to examine is the effects such enduring developments had on the progress and identity of the conferences and how these can be identified from exploring the contents of those last meetings. Always diverse, it is certainly noticeable that by now the range of topics addressed was broader and more diffuse than before and overall seemed to lack something of the focus of those earlier gatherings - the 1936 conference for instance contained papers concerning Recent Advances in African Education, the Social Life of the Teacher, the City Literary Institute and the World Congress of Faiths. As these representative titles would indicate, there was also a greater lack of papers pertaining to experimentation of the sort that had so characterised those meetings during and just after the war. This thus seemed to represent a dilution of one of the key planks of the movement. Indeed, where such aspects were addressed they originated instead from speakers from within the fee-paying sector - the last conference for instance contained papers delivered by those associated with Bedales, Gordonstoun, Dartington and Bryanston School. This was certainly a far cry from the many state elementary teachers who had been keen to contribute earlier on.

Even in spite of those particular progressive initiatives such as the Hadow Reports, it seemed that, by this late stage, the radicalism of the New Ideals group had been somewhat tempered, perhaps on account of the altered and reduced composition of its membership. Records indicate that only 139 people attended the 1936 Conference and, of these, only a handful had been present at those initial meetings nearly a quarter of a century earlier. It is also pertinent to see that many of those listed are classed as 'Speaker' or 'Student' which further suggests something of the group's diminishing relevance to wider networks. This was also reflected in the cessation of the New Ideals Quarterly, which had been wound-up the previous year due to

\footnotetext{
${ }^{78}$ 'Introductory' in New Ideals in Education: 4th Conference Papers (1917), ix.
} 
lack of subscription funds. No-where perhaps were these changes better illustrated than by the Address of Welcome of 1936 which was given by Cyril Norwood, President of St. John's College Oxford and formerly Headmaster of Harrow School (1926 - 1934). Something of an anachronism, Norwood's Classical mind set which conceived of different types of education for different types of mind, was to be a forerunner of the post-War 11+ system and its heavily examined provision would have surely repulsed those former Presidents Lytton and Holmes. Indeed, the death of the latter in 1936 prompted two tributes by R.W. Macan and E. Sharwood Smith which tellingly recognised the prior contribution of his life and work yet also seemed to indicate a finality to the movement he himself had been so instrumental in founding. ${ }^{79}$ It is perhaps no coincidence that as Holmes' contributions had diminished in the 1930s (he resigned the committee Chairmanship in 1931) so too had the New Ideals begun its own terminal decline.

All of this serves to indicate that, like so many whose foundations are built on a sense of spirit and loose ideology rather than formal proclamation, the New Ideals group had reached the end of its natural life. Figures like Holmes, Lytton, McMillan and Baden-Powell seemed by now to be redolent of another age and with the coming of the grammar schools and the promise of meritocracy, the aspirations of the working classes and perhaps their teachers were now aimed at more than spiritual enlightenment and philosophical conceptions of freedom. After 1944, many thinkers who saw themselves as progressive - Brian Simon and A.H. Halsey for instance - focussed their efforts upon the effects of selection and social class and not on the more esoteric and a-political agenda as had been sought by the New Ideals members. Theirs after all had been a response shaped by a very peculiar set of contextual conditions, notably a way to fill the ideological vacuum left by the war. There is also perhaps something to the claim of R.J.W. Selleck that by 1939 such ideas had anyway 'become the

\footnotetext{
${ }^{79}$ See R.W. Macan, 'The Address of Welcome' 1-17 and E. Sharwood Smith, 'Edmond Holmes Memorial Lecture' 39-49 in New Ideals in Education: 24th Conference Papers (London: New Ideals Committee, 1937).
} 
intellectual orthodoxy', ${ }^{80}$ thereby removing the very purpose upon which the movement had been founded.

\section{Conclusion}

In summary, the New Ideals movement began as one organised by the disciples of Montessori, but the dramatic events of the First World War, as well as a philosophical desire to be anti-dogmatic, meant that their presence was rapidly lost as more adherents and supporters were gained driven by the broad aim of freedom for the child. Whilst this very term was not one easily defined - except perhaps in the sense of being against the imposed authority of an adult - and fighting shy of any desire to be a political or, for that matter, a social movement the New Ideals conferences undoubtedly resonated with vitality and an intellectual energy which was a happy accident of the context in which they originated. Much of this vigour was put to use not merely in sharing and embodying best practice but also in seeking to put those practices to work in the post-war world which, it was thought, had urgent need of a more Romantic and child-centred sensibility.

Although these more abstruse notions were not borne out in the sense of forming part of a long-term ideological shift in education - only really within particular private experiments were such ideas pursued more fulsomely - they did for a time find a comparatively wide base of support amongst practitioners working within the state sector. Although not representing the political rights of teachers, the New Ideals conferences did ensure a space in which new ideas could be shared, wider policies could be discussed and relationships could be struck with those in a range of cognate fields. Much of the latter was a direct result of the attitude of the New Ideals group, which was one of dialogue and glasnost with those in authority, many

\footnotetext{
${ }^{80}$ R.J.W. Selleck, op., cit., (1972), 153.
} 
of whom were anyway equally keen to co-operate in finding a solution to the contemporary crisis, which was seen as stemming from the dogmatism and militarism within Germany.

More widely, the New Ideals group can also be seen as having an intimate connection with other nascent educational groups at the time and can be seen as appearing at crucial stages in their emergence. The Theosophical Fraternity, for example, was sufficiently encouraged by their work that they sought to send their members to investigate the conferences, whilst the NEF can be seen as emerging directly from the precepts laid down by the New Ideals. One thing that all these groups did share was a passion for freedom, a term which as we have seen had a range of connotations including spiritual, political and pedagogical. Amongst the New Ideals group, this was particularly reflected in the ways in which much of their support was given either to existent classroom teaching or else institutions which sought retreats from reality, often through the development of alternative, rural ways of living. It was perhaps for this reason - as well as such ideas acquiring a more common currency - that over time its purpose became less than clear and it ultimately folded at a point in which education was about to enter a new phase. However, this should not be to underestimate its role in contributing to the spread and dissemination of progressive ideas, and organizationally how it acted as a model in showing how those from within different sectors within education and attendant professions could and perhaps should work together. 